\title{
The Possibility of Nationalization by the Kurdistan Regional Government of Iraq under the Light of Signed Petroleum Contracts and Establishment of Kurdistan National Oil Company (KNOC)
}

\author{
-Analytical study -
}

\author{
Arez Mohammed Sediq Othman \\ Department of Law, College of Law, University of Sulaimani, Sulaimani, Kurdistan Region -Iraq
}

\begin{abstract}
In the past 20 years, Kurdistan Regional Government (KRG) of Iraq has signed hundreds of Production Sharing Contracts with many international oil companies to expand investment and develop its oil sector. According to the applicable laws in the region, in particular Oil and Gas Law No.22 of 2007, government shall work to establish Kurdistan National Oil Company (KNOC) to take charge of petroleum operations. Meanwhile, according to the same law, the duration of petroleum production sharing contracts shall not exceed 20 years with the possibility of five years extension. Despite the fact that KRG is abided to many legal obligations to share the produced oil under production sharing contracts, there is always a question of whether KRG will be able to administer its oil industry and what will be the future of these oil contracts? This paper argues that KRG cannot nationalize (by appropriating the whole oil industry and assets of foreign oil companies) its petroleum sector even after the establishment of KNOC as there are many legal terms preventing it from nationalizing the oil industry besides the lack of technical ability to run the sector without the direct support from foreign oil companies. Moreover, the paper also discusses different possibilities after the end of oil contracts with foreign international companies; Does KRG continue with the current contractual form or it will shift to other forms of contract such as service contract to develop oil industry in the region? It suggests that the best practice for the government is to institutionalize its oil sector with receiving direct support from oil companies. The establishment of KNOC is considered to be an effective step towards institutionalization of oil sector in the Iraqi Kurdistan Region.
\end{abstract}

Index Terms - Nationalization, Production Sharing Contracts, Appropriation, Kurdistan National Oil Company, Service Contract, Sovereign Immunity, Fair Compensation, International Oil Companies.

\section{SECTION ONE: INTRODUCTION}

In Iraq, the history of exploration and production of oil is traced back to the beginning of last century after the First World War when in 1925, King Faisal signed a concession agreement with Iraq Petroleum Company (IPC) which was a consortium of British, French and American oil companies for the duration of 75 years (Greg, 2005, p.5-6). The very unfair content and terms of concessions have led to the wave of nationalization which started in 1962 and all the oil industry had been nationalized by the Iraqi government in 1975 (Christopher, 2009, p1-3). In supporting the accelerating of nationalization process, in 1964, Iraq has established National Oil Company under the rule of Baath Party to grow the concession expanses which was controlled by the IPC and taken over by the Iraqi government later in 1975 (Valerie, 2006, p.23-24). Thus, Iraq is one of the countries that adopted concession system alongside other Middle Eastern countries during the first half of the twentieth century (Atef, 1988, p.2-3). Several terms have been used to describe various situations in which a host state take over properties owned by foreign investors or companies; the most common ones are nationalization and appropriation. It is used to label a serious of actions taken by host state from "the sudden enforcement of previously unenforced foreign controls to outright confiscation and physical takeover" (Lianlian \& John, 1994, p.139). Appropriation is considered by many scholars as a forbidden practice in international law unless there is a just compensation to the other party (Kunz, 1940, p.327-330). In the Iraqi Kurdistan Region, the host government has signed many petroleum contracts with the international oil companies. Despite inserting many legal safeguards by foreign investors in their petroleum agreement with the KRG, Nationalization or

Journal of University of Human Development

Volume 6 No. 1(2020); DOI: 10.21928/juhd.v6n1y2020.pp35-43

Regular research paper: Received 23 February 2020; Accepted 12 March 2020; Published 15 March 2020

Corresponding author's e-mail: arez.sediq@univsul.edu.iq

Copyright (C) 2020 Arez Mohammed Sediq Othman. This is an open access article distributed under the Creative Commons Attribution License (CC BY-NC-ND 4.0) 
appropriating foreign oil companies' assets and terminating the contracts is a continues concern. The paper investigates the possibilities of nationalization of the petroleum sector in the Kurdistan Region of Iraq under the light of signed production sharing contracts and applicable legislations such as Iraqi Constitution 2005, KRG's Oil and Gas Law No.22 of 2007 and international practices.

\section{Research Question}

Does KRG has right to nationalize its petroleum sector under current applicable legislations? Would the production sharing agreements with oil companies allow KRG to recourse to such step? What are international practices in this regard? Will international oil companies be compensated if such actions take place? When will KRG be legally and technically ready to run (nationalize) its oil sector without sharing oil production with foreign companies? The paper is trying to answer these aforementioned inquiries.

\section{Research Importance}

Kurdistan Region of Iraq has been seen by foreign oil companies as a great potential for investment. In assessing political and legal risks, nationalization or appropriation is considered a great danger to the future of investors in any foreign countries. This paper has analysed the likelihoods of nationalizing oil sector by the Kurdistan Regional Government of Iraq and the consequences of such action in the presence of many legal restrictions both nationally and internationally. The paper has focused on applicable legislations and signed petroleum contracts that can be legal barriers in taking any step toward nationalization. No analytical research has been conducted before in this field; the paper can be an academic resource to various stakeholders and above all the government and foreign oil companies operating or willing to operate in Kurdistan's oil sector in the future.

\section{Research Outline}

In the consistent manner, the paper has been divided into five main sections; besides introduction in the first section and conclusion (recommendations) in the fifth section. In the second section, legal barriers before nationalization of oil industry by Kurdistan Regional Government have been discussed. The readiness of the Kurdistan Regional Government to nationalize its oil sector has been analyzed in the third section. In section four, the consequences of nationalization have been discoursed.

\section{SECTION Two: LEGAL BARRIERS IN FRONT OF KURDISTAN REGION TO NATIONALIZE ITS OIL SECTOR}

In this section, legal barriers that prevent KRG from taking actions toward nationalization will be discussed; legal barriers refer to any legal obligations that the KRG is bound by.

The early examples of nationalization are traced back to the first half of twentieth century, the first following the Bolshevik Revolution of 1917 in Russia and the second in 1938 in Mexico. During the 1970s, however, virtually all of the oil resources outside of North America passed from international petroleum companies to the governments of the oil producers (Edward, 1999, p.4). In the Middle East, particularly in Iraq, the country had concluded a series of concession agreements in the $1920 \mathrm{~s}$ and 1930s. Later in 1940s, the Iraq Petroleum Company and its two wholly owned subsidiaries, the Mosul Petroleum Company and the Basra Petroleum Company entered into a comprehensive concession to develop and export almost the entire oil fields in Iraq. However, soon after concluding these agreements, the Iraqi government realized the balance in the terms and conditions compared to other neighboring countries in Middle East, which led to seeking changing the content of the contracts. Particularly, between 1949 and 1952, Iraq has sought higher return from Iraqi Petroleum Company as the gain of neighboring countries was much higher than Iraq. For instance, in March 1948 Saudi Arabia's return (for its land area) raised up to 12 shillings per ton; in June 1948 Kuwait gained more than 12 shillings per ton for its share of the Neutral Zone with Saudi Arabia; in October 1948 Saudi Arabia received more than 13 shillings per ton for its continental shelf; in January 1949 Saudi Arabia received 21 shillings per ton for its share of the Neutral Zone with Kuwait; and in July 1949 Iran's compensation (under the terms of an agreement which Iran refused to ratify) was scheduled to increase to at least 14 shillings per ton. Iraq's royalty was determined by 5 shilling gold in its all concessions which was least compared to other countries in the region (Daniel, 1996, p.69-70). These imbalances in contract privileges and the least control over petroleum sector by the Iraqi government have to some extend justified the act of nationalization by the Iraqi government. However, speaking about the KRG's oil sector, the story is different in many ways and the host government (KRG) is legally restricted in stepping toward nationalizing the oil sector, at least in the current stage. In this section the lack of sovereign immunity in KRG's oil transaction is conferred and the extend of which KRG's action toward nationalization should be considered an excuse of Acts of God to halt oil companies' operation.

\section{Waiver of sovereign immunity in commercial transactions}

There is consensus among legal scholars that state agencies are exempted from all kinds of immunities in conducting commercial transactions with foreign contractor; they claim that the restricted theory of sovereignty should be applied in a way consistent with the existence of a horizontal international order. Scholars support the application of what is known as restrictive theory of sovereign immunity. The core application of this theory depends of the use of some criteria that can be relied on in distinguishing governmental acts of government with those that has commercial characteristic (Kindred, 1980, p.624-627). Sornarajah has stated that "where the transaction of a State agency is clearly commercial, it would be fair to expect that the State would accept that its obligations, as identified by a foreign domestic court, should be fulfilled. It is in the selfinterest of a State agency to do so, for its credibility would suffer if it refused to fulfill its commercial obligations." (Sornarajah, 1982, p.665). However, there is a view which supports the idea that nationalization by host country toward foreign oil companies is the act of nationalization that breach a long-term concession agreement granted to petroleum companies and it is a rightful act. These companies tended to receive a huge portion of oil in return of small amount of 
privilege to the host country similar to what had taken place between Iraqi Petroleum Company and Iraq (Sornarajah, 1982, p.673-674). In many cases, the termination of these concessions had conducted by legislative approval and the enactment of Law. For example, the Law of Nationalization of Operations of the Iraq Petroleum Company Limited, No. (69) of 1972 by the Iraqi government. Meanwhile, the act of nationalization by Iraqi government was aligned with the issuance of the UN General Assembly Resolution on Permanent Sovereignty over Natural Resources which insist on 'The right of peoples and nations to permanent sovereignty over their natural wealth and resources must be exercised in the interest of their national development and of the well-being of the people of the State concerned.' (Article 1 of the UN General Assembly Resolution, Permanent Sovereignty over Natural Resources, 1803 (XVII) of 14 December 1962).

According to the applicable laws in Kurdistan Region of Iraq, any contractor who wants to get authorization to operate in any oil field in determined area will not be subject to the Public Procurement Regulation No.2 of 2016; meaning that the contract has special nature and it will be dealt as a commercial contract not a governmental contract in which government has absolute sovereignty and power toward the other party. The instruction clearly states that "The provisions of these Regulations shall not apply to the award by the Ministry of Natural Resources of authorizations and contracts for petroleum operations in the Kurdistan Region. These contracts remain subject to the provisions of the applicable Kurdistan Region's oil and gas law." (article 3(third) of the KRG's Public Procurement Regulation No.2 of 2016). The same content has been mentioned in Instructions for Implementing Government Contracts No.2 of 2014 (article 1 (second) of Instructions for Implementing Government Contracts No.2 of 2014). In awarding contracts to private contracts, Minster of Natural Resources in KRG would directly enter into negotiation. The KRG's Oil and Gas Law states that "The Minister may, where it is in the public interest to do so, elect to award Authorisations through direct negotiation." (Article 26/first (2) of the KRG's Oil and Gas Law No.22 of 2007). The same law granted power to the minister to waive all claims of sovereign immunity regarding legal proceedings and enforcement of judgement in the region (Article 43 of the KRG's Oil and Gas Law No. 22 of 2007). These are the indication that petroleum contract is considered to be a private contract between two private parties, not a governmental contract in which the government can practice all powers toward the other party. Moreover, the signed production sharing contracts between the KRG and the foreign international oil companies contains provisions which can waive immunity from both government and contractors. Article 41 of the KRG's production sharing contract model have stated that "The government and any Public Company which may be a contractor Entity at any time hereby fully and irrevocably waives any claim to immunity for itself or any of its assets. This waiver includes any claim to immunity from:

(a) any expert determination, mediation, or arbitration proceedings commenced pursuant to Article 42;

(b) any judicial, administrative or other proceedings to aid the expert determination, mediation, or arbitration proceedings commenced pursuant to Article 42; and (c) any effort to confirm, enforce or execute any decision, settlement, award, judgment, service of process, execution order or attachment (including pre-judgment attachment) that results from an expert determination, mediation, arbitration or any judicial, administrative or other proceedings commenced pursuant to this Contract.

Thus, it might be said that the government (KRG) cannot claim sovereign immunity under any circumstances, and any action toward nationalization under the excuse of sovereign immunity is rejected as KRG has entered into these contracts as a commercial party. For instance, this has been clearly emphasized in the The Foreign Sovereign Immunities Act of the USA, when it makes assumption that nationalization without payment of "prompt, adequate effective" compensation is contrary to international law. The seizure of nationalized property which finds its way into U.S. jurisdiction would protect by sovereign immunity (Sornarajah, 1979, p.108). Moreover, foreign oil companies in their signed production sharing contracts with KRG have insisted on maintaining the application of applicable rules and regulations at the time of signing the contract throughout the lifecycle of their agreement. All the changes in legislations or enactment of new law that occur and deemed to be applicable on their relationship shall be mutually agreed upon. Thus, any attempt by the Kurdistan Region to nationalize oil sector, even by the enactment of legislation, will be void according to the production sharing contracts. The example of this clause can be seen in article 43 of the KRG's model of signed production sharing contracts when it states that the government has responsibility to guarantee the maintenance of the stability of the fiscal and economic conditions of this Contract, as they result from this contract and as they result from the laws and regulations in force on the date of signature of this contract. All the applicable laws at the effective date of the contract will remain the same. If any changes happen which has reverse impact on fiscal and economic condition of the contractor "the terms and conditions of the contract shall be altered so as to restore the contractor to the same overall economic position as that which contractor would have been in, had no such change in the legal, fiscal and/or economic framework occurred". Therefore, this is considered as a legal barrier before the KRG to nationalize its oil sector under the current terms and conditions of the applicable contracts.

On the other hand, it is worth mentioning that the content of the signed production sharing contracts by KRG has not adopted certain mechanism to allow the parties of the contract asking for restructuring the contract by renegotiating the terms and conditions. Moreover, the Iraqi Constitution of 2005 has granted legal protection to private property and banned all kinds of expropriations. Article 23 has articulated that "Private property is protected, the owner shall have the right to benefit, exploit and dispose of private property within the limits of the law." (Article 23(first) of the Iraqi Constitution 2005). Further, the applicable investment law in Iraq, Number 13 of 2006 (the "Iraq Investment Law") provides that an Iraqi or foreign investor shall enjoy all of the privileges, benefits and guarantees set out in the aforementioned law (Article 10 of the Iraqi Investment Law No.13 of 2006). The same privileges have been emphasized in the KRG's Investment Law No.4 of 2006 "The 
foreign investor and capital shall be treated as the national investor and capital. The foreign investor shall have the right to own the entire capital of any project that he establishes in the region under this law." (Article 3 of the KRG's Investment Law No.4 of 2006). These provisions are considered to be a legal recognition to the valid right of foreign oil companies as a foreign investor to work in Iraq and their rights have been guaranteed by law. Additionally, the Iraqi Companies Law Number 21 of 1997 (as amended in 2004) (the "Companies Law") had prohibited foreigners from participating in Iraqi companies. However, an amendment to the aforementioned law was made in 2004 to allow foreigners to participate in and entirely own Iraqi companies, except in specific cases such as commercial agencies which must still be Iraqi owned. Given that companies incorporated in Iraq are considered Iraqi pursuant to Article 23 of the Companies Law and have a distinct legal personality and financial position irrespective of the nationality of its shareholders, these companies may acquire properties in Iraq (Mohammed Norri, 2017). Originally and by looking at international practices, nationalizations were taken place to foreign companies. However, this fact will not underestimate the right of national companies (who take part in oil sector as a private company) toward government, particularly when it comes to ask for an adequate compensation. Any action toward nationalization of foreign assets in Kurdistan Region is interpreted as a clear violation of these legislations. The only legal excuse that can be using to suspend the performance of obligation under the contract is the accident that prevent field work and known as Acts of God. In the following part, this will be explained.

\section{Can nationalization be considered as an Acts of God?}

An Acts of God or what is known as "force majeure" (French for "superior force") is a contract clause that relieves the parties from performing their contractual obligations when certain circumstances beyond their control arise, making performance inadvisable, commercially impracticable, illegal, or impossible (Damian, 2011). The same content has been defined by the Iraqi Civil Code No. 40 of 1951 (Articles 211 \& 899 of the Iraqi Civil Code No.40 of 1951). The reason why this is coming to discussion is because it is one of the legal ways to refrain from performing an obligation. By looking at the production sharing contract signed by the Kurdistan Regional Government, it can be observed that both parties have legal obligation to the duties assigned in the contract unless something take place outside either parties' control. This is explained in a section under Force Majeure. The contract states that "No delay, default, breach or omission of the contractor in the execution of any of its obligations under this contract shall be considered a failure to perform this Contract or be the subject of a dispute if such delay, default, breach or omission is due to a case of Force Majeure". (Article 40 (1) of the KRG's model of Production Sharing Contracts ). For the purpose of this contract, Force Majeure has been clearly defined as any event that is unforeseeable, insurmountable and irresistible, not due to any error or omission by the contractor but due to circumstances beyond its control, which prevents or impedes execution of all or part of its obligations under this contract. Such events shall include the following: (a)war, whether declared or not, civil war, insurrection, riots, civil commotion, terrorism, any other hostile acts, whether internal or external;

(b)strikes or other labour conflicts;

(c) accidents or blowouts;

(d) quarantine restrictions or epidemics;

(e) any act, event, happening or occurrence due to natural causes, in particular, but without limitation, floods, storms, cyclones, fires, lightning, or earthquakes;

(f) environmental restrictions, which the government has not notified to the contractor;

(g) except in respect of the government and/or any Public Company which may be a contractor Entity, any acts or orders of the government, any minister, ministry, department, subdivision, agency, authority, council, committee, or other constituent element thereof, any corporation owned and/or controlled by the any of the foregoing; and

(h) any acts or orders of any other government claiming or asserting jurisdiction over the subject matter of this Contract, any minister, ministry, department, sub-division, agency, authority, council, committee, or other constituent element thereof, or any corporation owned and/or controlled by any of the foregoing (Article 40 (2) of the KRG's model of Production Sharing Contracts).

Thus, it can be seen that only in case of Force Majeure parties can refrain temporarily from implementing their legal obligations and under no circumstances the desire to nationalize oil sector can be considered Force Majeure for the host government to halt the operations as it is purely intentional action. The term originally inserted to safeguard the rights of the contractor in case they cannot perform due to the reasons out of their control not government which owns absolute power.

\section{SECTION THREE: KuRdistan REGION's READINESS TO NATIONALIZE ITS OIL SECTOR}

Currently, the Kurdistan Region of Iraq has entirely depended on one form of contract known as production sharing contract, to share produced oil with foreign oil companies in predetermined portions (Article 24 (first) of the KRG's Oil and Gas Law No.22 of 2007). When it started exploring oil, Kurdistan Region did not possess any experience in oil sector as it was recently found on its land. In this contractual form, production sharing contract, the host government will entirely rely on the skills and knowhow of the oil company from exploration stage until production of oil, the host government has just a role of monitoring all procedures and after oil production, the found oil will be shared between the host country and oil companies (Nutavoot, 2004, p.434). The oil sector in Kurdistan Region is not completely discovered and there are still potentials for investment in Kurdistan's oil sector. In this section, the likelihood of changing contractual form from production sharing contracts to service contract by the KRG and the establishment of Kurdistan National Oil Company are discussed. 


\section{Shifting from Production Sharing Contracts to Service Contracts}

Nationalization has been seen as an effort to end exploitative terms imposed by the concession system in most of the countries in the region. In order to bring more skills and knowhows and provide continues support to its petroleum sector, Iraq has started to sign service contracts which can be defined as "a long term contractual framework that govern the relationship between a host government and international oil companies (IOCs) in which the IOCs develop or explore oil or natural gas fields on behalf of the host government in return for predetermined fees and in which in most cases the host government does not hand over the control of the extracted or subsoil or sub surface resources to the IOCs." (Abbas \& Cynthia, 2014, p.2). On the other hand, KRG has adopted a rather different system to develop the exploration and production of its oil sector; it is production sharing contracts with many foreign international companies (Article 24 (second) of the KRG's Oil and Gas Law No.22 of 2007). Despite allowing any contractual forms to be implemented by the KRG in developing its petroleum industry, adopting production sharing contract has been decided by the KRG's Oil and Gas Law No.22 of 2007; the law states that "A Petroleum Contract may be based on a Production Sharing Contract, or on other contracts which the Minister considers to provide good and timely returns to the people of the Region, as stated in Chapter 10 of this Law." (Article 24 (second) of the KRG's Oil and Gas Law No.22 of 2007). The details of this form of contract have been stated throughout the law (Articles 12, 24, 37, 54 of the KRG's Oil and Gas Law No.22 of 2007). The development period after discovery of oil has been determined as 20 years with the possibility of 5 years extension (Article 37 (first/4) of the KRG's Oil and Gas Law No.22 of 2007). Article 37 of the law has opened door to negotiate further for the possibility of further extension as the law states "with possible further extensions to be negotiated". This will raise a question of whether KRG will extend sharing oil products with oil companies or it will be capable of running its petroleum sector and sign different type of contract such as service contracts? According to the signed production sharing contracts, the KRG has responsibility to fulfil legal obligations toward foreign international oil companies. The contracts designed in a way not permitting the KRG to nationalize without the consent of the contractors.

(Table one)

Fiscal arrangements of different contractual form (Abbas \& Cynthia, 2014, p.2)

\begin{tabular}{|c|c|c|c|}
\hline & Concession & $\begin{array}{c}\text { Production } \\
\text { Sharing } \\
\text { Contract }\end{array}$ & $\begin{array}{c}\text { Service } \\
\text { Contract }\end{array}$ \\
\hline $\begin{array}{c}\text { Oil field } \\
\text { ownership }\end{array}$ & IOC & Host Country & Host Country \\
\hline $\begin{array}{c}\text { Crude } \\
\text { production } \\
\text { ownership }\end{array}$ & IOC & $\begin{array}{c}\text { Host Country \& } \\
\text { IOC }\end{array}$ & Host Country \\
\hline $\begin{array}{c}\text { Oil field operator } \\
\text { How the IOC is } \\
\text { compensated }\end{array}$ & IOC & IOC & $\begin{array}{c}\text { Host Country } \\
\text { \& IOC }\end{array}$ \\
\hline $\begin{array}{c}\text { Who bear the } \\
\text { risk }\end{array}$ & IOC & $\begin{array}{c}\text { A share of } \\
\text { production }\end{array}$ & Flat fee \\
\hline
\end{tabular}

As it has been indicated in the table (table one), alongside concession when the field almost owned and run by international oil companies, the major difference between production sharing contract and service contract is on crude oil ownership and operating the oil field which is administered by the host country. Other areas are similar to production sharing contract. It can be said that despite the fact that owning the crude oil and operating the oil field are considered two main privileges for the host country as they directly related to government earning, the Kurdistan Regional Government even if they shift to service contract cannot take advantage from these privileges as there will be a question of sovereignty. The KRG does not want to raise an issue of sovereignty as it does not possess sovereignty; it is a federal region within Iraq. KRG has already had legal disputes with the federal government over the authority of signing petroleum contracts; the Federal Government see it as its pure jurisdiction to sign any petroleum contracts in Iraq, including those by KRG. This is a suspended unresolved issue between the two governments and both have chosen silence. Thus, if KRG take the step toward changing the contracts to service contracts, there is a risk that the Iraqi Federal Government claim authority to sign the contract and operate the oil fields. It can be argued (we recommend) that for the Kurdistan Region of Iraq, it is recommended to operate under the current production sharing contract despite having drawbacks and loopholes in this contractual form.

The service contracts adopted by the Iraqi Federal Government will not be admissible for Kurdistan region. This contractual form will be implemented by countries that have already run its oil industry and it is not considered a lucrative incentive to attract foreign oil companies compare to production sharing contracts when the company will share production with the host government. Talking about history and experience, Iraq has started nationalization in 1962 after almost 40 years exploration and production of its oil industry by a group of US, UK, France and Dutch companies in the 1920s. On the other hand, KRG has quite recent history and limited technical experience. For instance, until now, the KRG has not been able to establish public companies determined in the Oil and Gas Law; it outsources nearly all operations to foreign companies.

\section{Nationalization through Kurdistan National Oil Company (KNOC)}

Creating national oil companies can be understood as a government step toward intervention in economy (Silvana and others, 2011, p.15). The major exporters of oil around the world gathered in Cairo in 1959 and signed a gentlemen agreement to agree on consulting each other on common interest issues. One of the recommendations was to create National Oil Companies to safeguard the direct participation of state in oil industry. Later in September 1960 Organization of the Petroleum Exporting Countries (OPEC) was established by Iraq, Iran, Saudi Arabia and Venezuela (Silvana and others, 2011, p.1718). There was a sense of exploitation among these countries toward the foreign oil companies working in their oil fields and concession was a major system adopted by these countries. As Heller reported "outside the United States, Canada, and the centrally planned economies, from 1963 to 1975 public sector 
control in the oil industry rose from 9 percent to 62 percent in production" (Silvana and others, 2011, p. 18). When Iraq had nationalized its oil sector, it established a company to supervise the nationalization procedures under the Law of Nationalization of Operations of the Iraq Petroleum Company Limited, No. (69) of 1972. The law states that "A government owned company called the Iraqi Company for Oil Operations will be established by virtue of this law and it will be considered established upon the entry into force of this law and all the money, rights and assets that have been transferred to the state will be transferred to this company." (Article 2(1) of the Law of Nationalization of Operations of the Iraq Petroleum Company Limited, No. (69) of 1972). Even prior to that, the Iraqi Government had started to reduce IPC's holding by issuing the Law No.80 in 1961, in particular, specific procedures to create National Oil Company (Report titled: Introduction to the Laws of Kurdistan, Iraq Working Paper Series, Oil and Gas Law of Iraq, 2018, p.7). The law aimed at collecting data on operating fields as a preparation for nationalization while sector (Article 5 of the Law No.80 of 1961).

Under the applicable Oil and Gas Law in Kurdistan Region of Iraq, Kurdistan National Oil Company should be established as a public company being a legal entity with independent finance and management (Article 11 (first) of the KRG's Oil and Gas Law No.22 of 2007). According to the law, the company shall work to achieve the following three main objectives:

First: compete with other companies to obtain Authorisations regarding the management of Current Fields; Second: enter into joint ventures with reputable and experienced international petroleum companies for Petroleum Operations to enhance production from Current Fields, to maximise early returns; Third: on a case by case basis, compete to obtain Authorisations regarding Future Fields (Article 11 (fourth) of the KRG's Oil and Gas Law No.22 of 2007).

By looking at the timing of the enactment of the law and the provisions of this article, it can be realized the purpose behind this article is more to increase efficiency and better management of oil sector than an intention toward nationalization. By creating this company, KRG wants to compete with foreign companies not replacing them with national oil company. The intention is to take advantage from the experience of international petroleum companies and transfer these skills to the region. In Iraqi government, in 1972, the law of Nationalization of Operations of the Iraq Petroleum Company Limited, No. (69) is very transparent and the government did not hide its intention to nationalization when its stated "The operations of the Iraq Petroleum Company Limited are nationalized in the areas designated for them according to Law No. 80 of 1961 and the state owns all existing facilities and rights related to the aforementioned operations, and this includes in particular facilities and facilities for exploration and drilling, crude oil and gas production, treatment, assembly, pumping, transportation, filtering, storage and major and field pipelines And other assets, including the company's mentioned office in Baghdad, with all its facilities and equipment" (Article 1 of the Law of Nationalization of Operations of the Iraq Petroleum Company Limited, No. (69) of 1972). On the other hand, the Iraqi Parliament has enacted the Iraq National Oil Company Law no. 4 of 2018. The major goal of this law is different from what has been decided in law of Nationalization of Operations of the Iraq Petroleum Company Limited, No. (69) of 1972. The overall content of this new law is similar to the Kurdistan National Oil Company determined in the KRG's Oil and Gas Law in 2007. However, unlike Kurdistan National Oil Company, the new Iraqi National Oil Company is intended to be more comprehensive and it conducts both upstream and downstream activities (Article 4 of Iraq National Oil Company Law no. 4 of 2018). The Kurdistan Region is far more behind Iraq in administering its oil sector as KRG's Oil and Gas law has provided a roadmap of establishing National Oil Company in Kurdistan without providing any details. Thus, it can be said that there is no indication that KRG has intention to establish National Oil Company to nationalize or appropriate oil fields operated by foreign oil companies. The tendency is toward a better management of oil sector and there are many other steps needed to be taken to have a more systematic and structured oil industry in Kurdistan Region.

\section{SECTION FOUR: COST OF NATIONALIZATION (FAIR COMPENSATION IN RETURN OF NATIONALIZATION)}

Expropriation, nationalization and other host-government takings are among the most frequently cited cases of political risk allied with foreign investment. Potential foreign investors often consider the presence of this class of risk as a main factor in decisions not to invest; the risk of expropriation is much higher compare to incentives of investment in a foreign country (Lianlian \& John, 1994, p.138-139). Some scholars have seen nationalization as a way of restructuring countries' economy and make it different from expropriation. Host states tend to justify nationalization under the concept of independency and extending their sovereignty over natural resources. For instance, Romania in June 1948 had justified its nationalization by indicating that "the nationalization... dates our economic and political independence, fortifies the forces struggle against the attempt at interference in our internal affairs rape of our independence, carried on by the Anglo-American imperialists." (Seymour, 1950, p.463).

The concept of economic self-determination and absolute sovereignty over natural resources have been embodied in the International Covenant on Economic, Social and Cultural Rights and the International Covenant on Civil and Political Rights. They clearly stated that "All peoples have the right of self-determination. By virtue of that right they freely determine their political status and freely pursue their economic, social and cultural development." (Article 1(1) of International Covenant on Economic, Social and Cultural Rights). And "All peoples may, for their own ends, freely dispose of their natural wealth and resources" (Article 1(2) of International Covenant on Economic, Social and Cultural Rights). Moreover, when it comes to nationalization and appropriation, article 4 of the UN General Assembly Resolution, Permanent Sovereignty over Natural Resources, 1803 (XVII) of 14 December 1962 states that "Nationalization, expropriation or requisitioning shall be based on grounds or reasons of public utility, security or the national interest which are recognized as overriding purely 
individual or private interests, both domestic and foreign. In such cases the owner shall be paid appropriate compensation, in accordance with the rules in force in the State taking such measures in the exercises of its sovereignty and in accordance with international law. In any case where the question of compensation gives rise to a controversy, the national jurisdiction of the state taking such measures shall be exhausted. However, upon agreement by sovereign, states and other parties concerned, settlement of the dispute should be made through arbitration or international adjudication." (Article 4 of the UN General Assembly Resolution, Permanent Sovereignty over Natural Resources, 1803 (XVII) of 14 December 1962).

In implementing nationalization by host country, one of the main problems, which have to be taken into account is the aggression of these countries toward the foreign companies and reluctance in recognizing the right of compensation (Seymour, 1950 , p.463-464). The common practice and rules of international law regarding appropriation of foreign assets is that taking private properties of foreign nationals shall be accompanies by the obligation to pay prompt, effective and adequate payment (Bullington, 1927, p.685-687). For example, the United States of America in its note to Mexico on April 1940 states that "the right to nationalize is "coupled with and conditional on the obligation to make adequate, affective and prompt compensation" (Hyde, 1939, p.112). The obligation to pay adequate compensation has also been emphasized in famous Iranian Nationalization Case. (nationalization case is American Int'l Group, Inc. v. Islamic Republic of Iran, 493 F. Supp. 522 (D.D.C. 1980). When Iraq nationalized Iraq Petroleum Company (US, France, UK and Netherlands) on $1^{\text {st }}$ of June 1972, One year later, on $28^{\text {th }}$ of February 1973, the concerned countries concluded a settlement agreement with the Iraqi Government by which the IPC had to pay the amount of 141 million GBP to the Iraq as unpaid royalty payment for the time period of 1964 to 1971 as the IPC did not fulfill its obligation during this time. In return, Iraq government had to pay 15 million ton of crude oil to IPC as a compensation for halting oil production (Junji, 2018, p.145). The payment of the compensation to IPC has been also stated in the Law of Nationalization of Operations of the Iraq Petroleum Company Limited, No. (69) of 1972 when it states "The state shall pay to the Iraq Petroleum Company Limited in compensation for what it has acquired to the state...". (Article 3 of the Law of Nationalization of Operations of the Iraq Petroleum Company Limited, No. (69) of 1972) Similarly, Libya had also paid nationalization compensation to US based on the net book value of the whole assets (Junji, 2018, p.145). The payment of compensation is not always denied by host states. For instance, the Iranian Government in their memorial before the ICJ has expressed that "It is clear that the nationalization of the property of foreigners, even if not unlawful on any other ground, becomes an unlawful confiscation unless provision is made for compensation which is adequate, prompt and effective." (Anglo-Iranian Oil Co. case, I.e.l. Pleadings, op. cit., para. 30).

In Iraq, the 2005 constitution has articulated three conditions for allowing expropriation, it should be conducted for the purpose of public goods, and it must be in return for just compensation with having regulated by law (there must be legislation). (Article 23(2) of the Iraqi Constitution 2005). The same provision is applicable on the operations of oil companies in Kurdistan Region of Iraq. Resorting to nationalizing its oil sector will subject KRG to the payment of adequate compensation and jeopardize its international reputation which will increase the risk of halting trade deal with the KRG as such action is also violating many legal and contractual obligations. Most importantly, according to the content of production sharing agreements signed by the Kurdistan Region with foreign oil companies, after reimbursing oil companies by dedicating cost oil, the host government will become a defacto owner of all the properties and assets set by the oil companies. Thus, nationalization might cause a great financial harm to KRG as the exploration and production cost oil will be reimbursed within the few years after starting oil production. It can be realized that currently Kurdistan region is in the stage of attracting foreign investors to develop all of its sectors, despite the probability of rapid gaining in any action toward nationalization, such step will harm its commercial reputation and increase political risk which provide a negative image of KRG that show a risky environment for investment before the international community. Thus, it is not wise to take any action toward nationalization; instead the KRG shall work to institutionalize its oil sector by establishing public companies determined in the KRG's Oil and Gas Law. Further, there are many other unexplored oil fields in the Kurdistan Region of Iraq that cannot be explored without the intervention of foreign oil companies. According to legal scholars, there is a consensus that compensation is the main element in return of expropriating foreign investment, but it is not the only one. Expropriating of foreign properties shall be conducted for "public purpose" and there should not be discrimination against foreign investors. These two principles should be taken into account alongside fair compensation (Ghassemi, 1999, p.89-108). Thus, KRG should take these elements into consideration before taking any step toward nationalization.

\section{SECTION Five: Conclusion (\& RECOMMENDATIONS)}

Assessing political, financial and legal risks is considered to be a top priority for foreign investor to invest their capitals in any country. The World had seen a wave of appropriation of foreign assets in the second half of twentieth century resulted in nationalization. Iraq is one of these countries that completed nationalization of its oil sector in 1975 after enacting the Law of Nationalization of Operations of the Iraq Petroleum Company Limited, No. (69) of 1972. After the collapse of previous regime in Iraq in 2003, Kurdistan Region of Iraq tended to be an attractive potential for many international oil companies. In this regard, the KRG has entered into hundreds of petroleum agreements in a hope to develop its oil industry. The paper has investigated the possibility of nationalizing oil sector by the Kurdistan Region and concluded that there are many legal barriers preventing the host government from taking over all the oil fields operating by foreign oil companies. The paper argued that despite the provision in the KRG's Oil and Gas Law in 2007 on the establishment of Kurdistan National Oil Company, the purpose behind this is different from the establishment of Iraqi National Oil Company in 1972 which was created to complete nationalization of Iraqi oil sector. The 
main goal of the Kurdistan National Oil Company is to provide a better management and compete with other companies to operate in the future oil fields. Further, the paper indicated that there are many provisions and terms in applicable legislations in Iraq that restricted KRG to take any step toward nationalizing its oil industry and expropriating foreign companies' assets in the region. The act of signing petroleum agreements is considered as commercial transaction and the host government does not possess sovereign immunity and cannot practice sovereign powers toward foreign oil companies. The paper has also discussed the readiness of the KRG and concluded that there are many reasons to believe that the region is not ready to administer its oil sector. Any step toward nationalizing oil sector in this stage will subject the international reputation of the KRG to a great risk. It also shed the light on the likelihood of the KRG to change its contractual form from production sharing agreement to service contract and argued that the KRG is bound by the content of the signed production sharing agreements, any changes shall be conducted by a mutual consent. The KRG is not ready to adopt service contract as there are many new oil fields that need exploration and production and the service contract is not a rightful choice to attract foreign oil companies.

In case the KRG desired to nationalize its oil sector, the international practice has proved that the cost of this process is heavy on the host country; providing fair and adequate compensation is a primary condition. The Iraqi Constitution of 2005 has emphasized on the prohibition of appropriation unless it there is a justice reimbursement. Thus, it can be said that despite the fact that there are many obstacles before the KRG to nationalize the oil sector, there is not a desperate need to take such step. The KRG is in a stage of attracting new investors and any action that harm foreign companies will also cause a great damage to the commercial reputation of the region and will result in retreating the flow of foreign investment. Instead, it is recommended that the KRG should accelerate the steps of establishing public entities such as Kurdistan Exploration and Production Company, Kurdistan National Oil Company, Kurdistan Oil Marketing Organization and Kurdistan Organization for Downstream Operations decided in the KRG's Oil and Gas Law No.22 of 2007. Establishing such entities will support the government to have a better management of oil sector and provide more transparency. The Kurdistan government shall take advantage from the experience of other oil rich countries to reorganize the sector. Moreover, KRG authority, in particular Ministry of Natural Resources shall review the terms and conditions of the signed agreement and prepare a strategic plan for the aftermath of current contractual relationships.

\section{REFERENCES}

\section{Primary Sources}

\section{First: Legislations}

- $\quad$ Iraqi Civil Code No. 40 of 1951.

- Law No.80 of 1961.

- Law of Nationalization of Operations of the Iraq Petroleum Company Limited, No. (69) of 1972.
- $\quad$ Iraqi Constitution 2005.

- $\quad$ KRG's Investment Law No.4 of 2006

- $\quad$ Iraqi Investment Law No.13 of 2006.

- $\quad$ KRG's Oil and Gas Law No.22 of 2007.

- Instructions for Implementing Government Contracts No.2 of 2014.

- $\quad$ Public Procurement Regulation No.2 of 2016.

- $\quad$ Iraq National Oil Company Law no. 4 of 2018.

\section{Second: Conventions and resolutions}

UN General Assembly Resolution, Permanent Sovereignty over Natural Resources, 1803 (XVII) of 14 December 1962.

International Covenant on Economic, Social and Cultural Rights

\section{Third: Cases}

Nationalization case is American Int'l Group, Inc. v. Islamic Republic of Iran, 493 F. Supp. 522 (D.D.C. 1980

Anglo-Iranian Oil Co. case, I.e.l. Pleadings, op. cit., para. 30.

\section{Secondary Sources}

\section{First: Book}

Junji Nakagawa, 2018, Nationalization, Natural Resources and International Investment Law, (Routledge).

Valerie Marcel, 2006, Oil Titans: National Oil Companies in the Middle East (Brookings Institution Press).

\section{Second: Journal Articles}

Abbas Ghandi and C.Y. Cynthia Lin, 2014 'Oil and Gas Service Contracts around the World: A Review'.

Atef Suleiman, 1998 'Oil Experience of the United Arab Emirates and Its Legal Framework', 6 J. Energy \& Nat. Resources L. No.1.

Bullington, Problems of International Law in the Mexican Constitution 2I Am. J. Int. L.

Christopher M. Blanchard, 2009, Iraq: Oil and Gas Legislation, Revenue Sharing, and U.S. Policy (Congressional Research Service 75700 .

Daniel Silverfarb, 1996, 'The Revision of Iraq's Oil Concession 1949-52, Middle Eastern Studies, Vol.32, No.1.

Edward L.Moris, 1999 'A New Political Economy of Oil?', Journal Of International Affairs, Vol 53, No.1.

Greg Muttitt, 2005 'Crude Designs: The Rio-off of Iraq's Oil Wealth', Global Policy Forum.

H. M. Kindred, "Foreign Governments before the Courts" (1980) $63624-$ 627.

Hyde, Compensation for Expropriation, 33 Am. J. Int. L.

Junji Nakagawa, 2018, Nationalization, Natural Resources and International Investment Law, Routledge.

Kunz, 1940, The Mexican Expropriations, 17 N.Y.U.L. REv. 327, 344.

Lianlian Lin \& John R. Allison, 1994, 'An Analysis of Expropriation and Nationalization Risk in China', Yale Journal of International Law, Vol 19.

M. Sornarajah, 1979, "Compensation Expropriation - The New Norms" 13, J.W.T.L.

M. Sornarajah, 1982, 'Problems in Applying Restrictive Theory of Sovereign Immunity', The International and Comparative Law Quarterly, Vol 31, No.4.

Nutavoot Pongsiri, 2004 'Partnerships in Oil and Gas Production-Sharing Contracts' 17(5) International Journal of Public Sector Management 431.

Seymour J.Rubin, 'Nationalization and Compensation: A Comparative Approach', 1950, The University of Chicago Law Review, Vol. 17, No. 3 . 
Silvana Tordo and others, 2011, 'National Oil Companies and Value Creation', World Bank Working Paper No.218.

\section{Websites}

Mohammed Norri, 2017, 'Foreigners Right to Own Real Estate in Iraq', available at [https://www.tamimi.com/law-update- articles/foreigners-right-to-own-real-estate-in-iraq/] accessed on 16 February 2020.

KRG's Ministry of Natural Resource [http://mnr.krg.org/index.php/en/downstream/data] accessed on $12 \mathrm{Feb} 2020$.

Damian McNair, 2011, 'Force Majeure Clauses', available at [file:///C:/Users/Dell/Downloads/forcemajeureclauses\%20(2).pdf 